\title{
Analysis of Selected Toxic Components in the Exhaust Gases of a CI Engine Supplied with Water-Fuel Emulsion
}

\author{
Paweł Kruczyński ${ }^{*}$, Piotr Orliński², Wojciech Kamela ${ }^{3}$, Marcin Ślęzak ${ }^{4}$ \\ ${ }^{1}$ BU Power Systems Polska Sp. z o.o., Krótka 6, 02-293 Warsaw, Poland \\ ${ }^{2}$ Department of Combustion Engines, Institute of Vehicles, Faculty of Automotive and Construction Machinery \\ Engineering, Warsaw University of Technology, Narbutta 84, 02-524 Warsaw, Poland \\ ${ }^{3}$ Department of Combustion Engines, Institute of Vehicles, Faculty of Automotive and Construction Machinery \\ Engineering, Warsaw University of Technology, Narbutta 84, 02-524 Warsaw, Poland \\ ${ }^{4}$ Motor Transport Institute, Jagiellońska 80, 03-301 Warsaw, Poland
}

Received: 8 May 2017

Accepted: 11 June 2017

\begin{abstract}
This study looks at the impact on selected toxic exhaust gas components in a compression ignition engine supplied with diesel-fuel emulsion. During the empirical research, a turbocharged PERKINS 1104C-E44T diesel engine was supplied with water-fuel emulsion where water content in the mixture was $15 \%$ by volume and diesel fuel. The tests were performed with load characteristics at two speeds of the engine crankshaft at maximum torque speed of 1,400 rev/min and maximum engine power speed of 2,200 rev/min. At each operating point of the engine concentrations of toxic exhaust gases we recorded carbon monoxide $\mathrm{CO}$, hydrocarbons $\mathrm{HC}$, nitrogen oxides $\mathrm{NO}_{\mathrm{x}}$, and particulate matter PM. On the basis of results and calculations, specific emissions of toxic substances in accordance with ISO 8178 were designated.
\end{abstract}

Keywords: exhaust gases, emissions, toxic components, diesel fuel, water-fuel emulsions, CI engine

\section{Introduction}

The automotive industry has a significant impact on the environment. During the combustion of fuels many types of air pollution are produced, the most important of which are: carbon dioxide, sulfur dioxide, nitrogen oxides, and dust. Moreover, other harmful substances such as carbon monoxide, soot, aromatic hydrocarbons, aliphatic hydrocarbons, tar, and heavy metal vapor (mercury, lead,

*e-mail: pkru1@wp.pl cadmium) are emitted in small quantities. Engine designers are trying to reconcile the conflicting requirements for reducing the harmfulness of the exhaust gases generated by engines with growing customer expectations for their cars to be dynamic and cheap to maintain. The main aim is to increase the efficiency of the engine by modifying the combustion process, thus reducing fuel consumption and emissions of toxic compounds produced by burning fuels. A very important direction of development of internal combustion engines are fuels that may contribute significantly to reducing toxic exhaust emissions. One way to reduce the concentration of nitrogen oxides and 
particulate matter in the exhaust gases is to provide water to the cylinder, for example in the form of a water-fuel emulsion, and this is reflected in published research results [1-3].

\section{Material and Methods}

At present, compression ignition engines are commonly supplied with diesel fuel, which is the product of petroleum refining. It must comply with strict parameters whose values are specified in EN-590. Crude oil is a finite product and its reserves are limited. This fact, as well as the growing industrial demand across the world for its products, may be the cause of a deficit of this resource in the future. Modern diesel fuels are constantly improved in order to be able to provide complete and efficient combustion in the engine and to minimize their harmful impact on the environment. One solution that can help achieve these goals is alternative fuels and fuel additives.

This alternative fuel may be, among others, a waterfuel emulsion. The delivery of water into the combustion chamber during the working cycle has been analyzed for several years [1, 4-7]. Water can be supplied into the combustion chamber in many ways. The two most popular solutions are a high-pressure water supply system and the previously mentioned water-fuel emulsions. Initially, the presence of water in the intake system was designed to support and even to eliminate the engine cooling system, but the research also established a positive effect on emissions of nitrogen oxides and particulate matter [2-3]. Microdroplets of water present in the emulsion vaporized faster than diesel fuel during combustion. Evaporating water generates micro-explosions and absorbs heat, which results in better mixing of diesel fuel droplets with air, decreasing the temperature in the combustion chamber. Combustion is more complete and the combustion reactions take less time [8]. Powering engines with waterfuel emulsions positively influences the engine working parameters, resulting in $\mathrm{NO}_{\mathrm{x}}$ and particulate matter emissions reduction, lowering fuel consumption, and ignition improvement. Studies [9-10] have shown that the supplying water-fuel emulsion reduces emissions of $\mathrm{NO}_{\mathrm{x}}$ by $18 \%$ and PM by $58 \%$ with $50 \%$ water content. Waterfuel emulsions have a number of disadvantages associated with their formation, stability, and storage. In order to provide diesel fuels miscibility with water, it is necessary to add emulsifiers, which reduce the surface tension of water [11]. In addition, high ambient temperature and foaming phenomenon have a very high impact on its low stability. The disadvantages include a higher freezing point, the need for injection process implementation, and the difficulty of forming an emulsion with the appropriate parameters comparable to conventional diesel fuels [11]. Possible elimination of the problems mentioned above will improve their injection process, which has a significant impact on the combustion process and the emissions of toxic components of the exhaust gas [12-20].
The tests were performed using a PERKINS 1104C-E44T turbocharged diesel engine. Load characteristics were designated at two speeds of the engine crankshaft: maximum torque speed of 1,400 rev/min and maximum engine power speed of $2,200 \mathrm{rev} / \mathrm{min}$. Fig. 1. shows a simplified diagram of the test bench.

During the measurements, the engine was supplied with diesel fuel and fuel-water emulsion, the basic parameters of which are shown in Table 1. The emulsion was formed with diesel fuel and water. The water content in the diesel fuel was $15 \%$ by volume. Fig. 2 shows the image of emulsion used in the course of research magnified by 400 times. Additionally, Fig. 3 describes the histogram containing the number of water droplets in the emulsion, depending on their diameter. It can be seen that the test emulsion is characterized by a high content of water drops with diameters from 2 to 7 microns. Microscopic analysis of the performed emulsion sample also showed that large amounts of water drops with diameters greater than 19 microns were not found. It must be noted, however, that the water-fuel emulsion is not a homogeneous mixture but a suspension. It therefore tends to delaminate over time $[11,21]$. While using water-fuel emulsion as fuel to power the engine, the gradual disappearance of the original microscopic structure and increase the size of the droplets of water in the diesel fuel must be taken into account $[11,21]$. Water-fuel emulsions can be divided into two groups: non-stabilized and stabilized [11, 21]. Stabilized emulsions are prepared in the vehicle, just before fuel is injected into the engine. Stabilized emulsions (as in the case of the emulsion used in the studies) contain additional chemical compounds (about 3\%) in the form

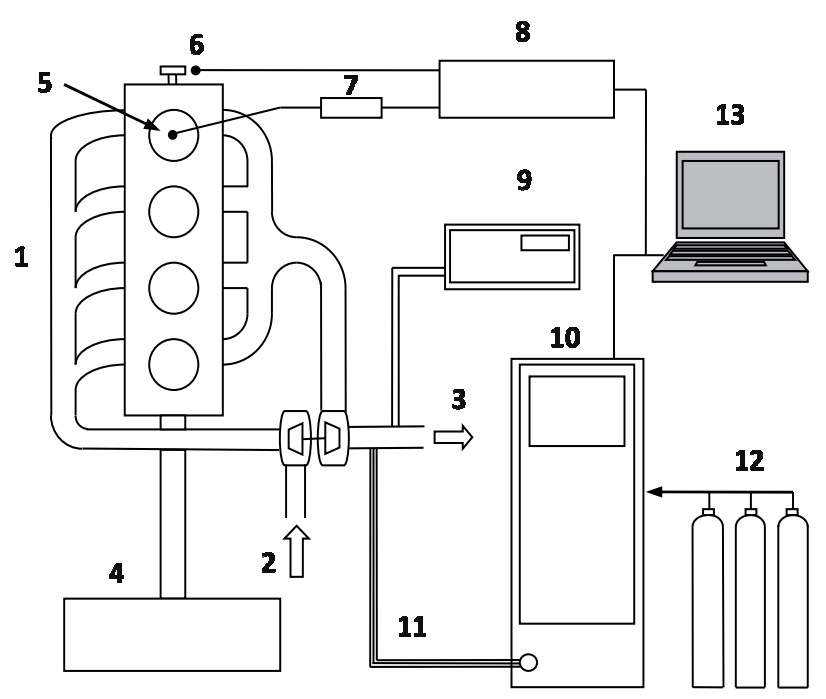

Fig. 1. Diagram of the test bench: 1) PERKINS 1104C-E44T engine, 2) air intake, 3) exhaust, 4) SCHENCK dyno brake, 5) AVL GM 12piezoelectric pressure sensor, 6) crank angle recorder, 7) signal amplifier, 8) AVL IndiSmart pressure measurement system, 9) Horiba Mexa 1230PM particulate matter analyzer, 10) AVL CEB II exhaust gas analyzer, 11) heated route, 12) sampling gases, and 13) measuring computer. 
a)

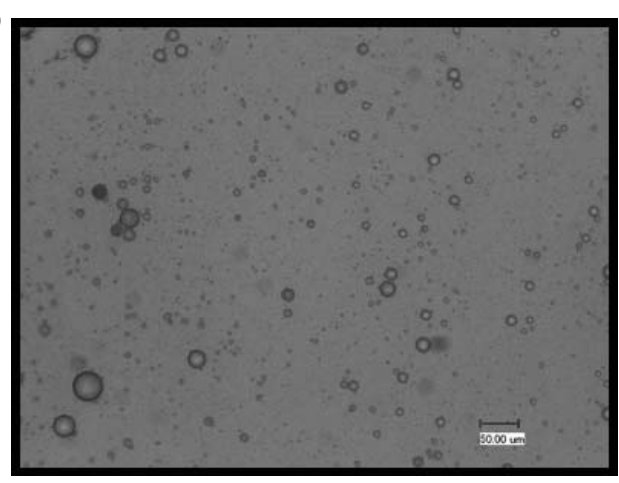

b)

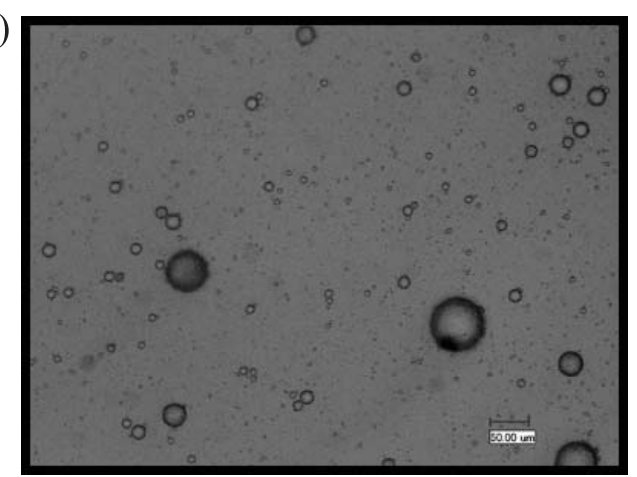

Fig. 2. Picture of water-fuel emulsion used in research enlarged 400 times: a) structure of emulsion after formation and b) structure of emulsion one month after formation.

of emulsifiers and stabilizers that allow for obtaining a sufficiently high degree of fragmentation of water drops and a longer delamination of the emulsion.

During measurements on the test bench at each operating point of the engine we recorded fixed operating condition concentrations of toxic exhaust gases, i.e., carbon monoxide $\mathrm{CO}$, hydrocarbons $\mathrm{HC}$, nitrogen oxides $\mathrm{NO}_{x}$, and particulate matter PM. On the basis of the recorded results and calculations, hourly fuel consumption, current fuel supply, and exhaust gas flow specific emissions of toxic substances in accordance with ISO 8178 for the two fuels were established using an MS Excel spreadsheet [22].

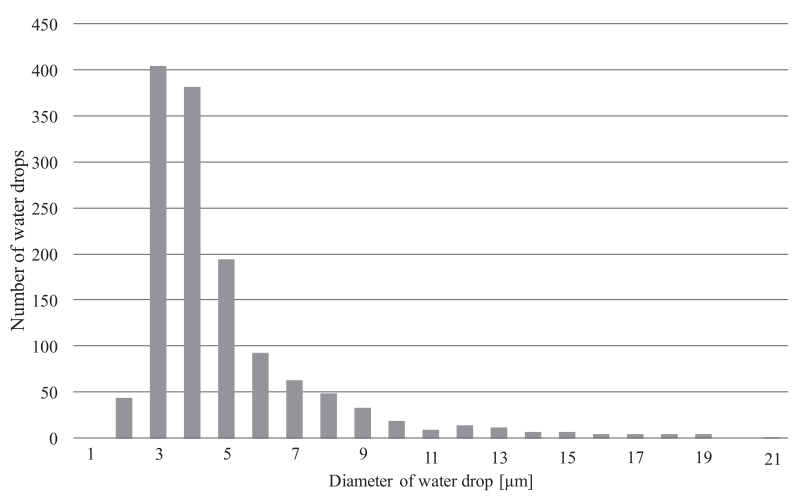

Fig. 3. Histogram showing the amount of drops in water-fuel emulsion depending on diameter after formation of the emulsion.

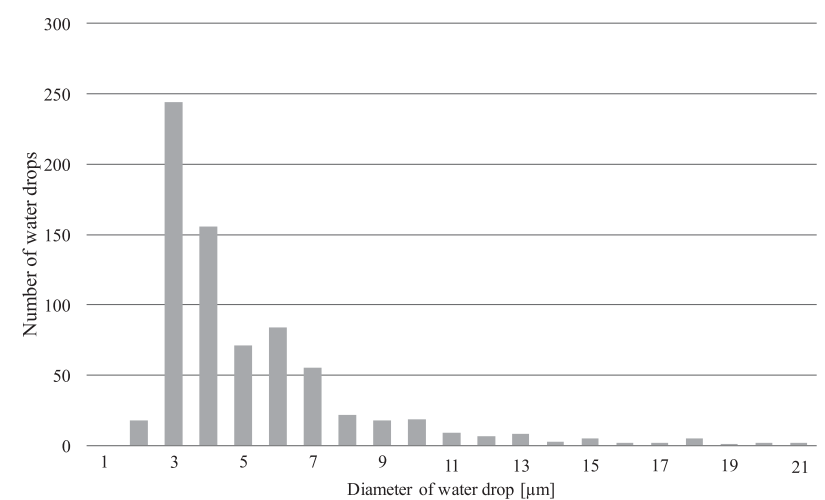

Fig. 4. Histogram showing the amount of drops in water-fuel emulsion depending on the diameter after one month from formation of the emulsion.

A simplified process is used to calculate the heat release rate by computing the energy the cylinder pressure effectively delivers to the gas. Surface losses are disregarded. Therefore, the heat release rate calculated is lower than the actual energy released. The calculation is based on the first law of thermodynamics. The heat release rate is calculated using the change of cylinder pressure in the following equation:

$$
H R R_{i}=\frac{K}{m-1}\left[m \cdot p_{i} \cdot\left(V_{i+n}-V_{i-n}\right)+V_{i} \cdot\left(p_{1+n}-p_{1-n}\right)\right]
$$

...where $\mathrm{n}$ is interval $\left(1^{\circ}\right.$ crank angle), $\mathrm{m}$ is polytropic coefficient, $\mathrm{p}$ is cylinder pressure (MPa), $\mathrm{V}$ is volume $\left(\mathrm{m}^{3}\right)$, and $\mathrm{K}$ is constant (100... due to unit conversion). It is also used to calculate other thermodynamics parameters, e.g., combustion start, ignition delay, and maximum cylinder pressure rise.

The temperature of the working fluid was calculated using van der Waals equation of state:

$$
T_{i}=\frac{\left(p_{i}+k^{2} \frac{a}{V_{i}^{2}}\right)\left(V_{i}-k b\right)}{k R}
$$

...where $\mathrm{a}$ is is a measure of the average attraction between particles, $b$ is the volume excluded by a mole of particles, $p$ is cylinder pressure ( $\mathrm{MPa}), \mathrm{V}$ is volume $\left(\mathrm{m}^{3}\right), \mathrm{k}$ is amount of substance in gas (moles), and $\mathrm{R}$ is universal gas constant.

Table 1. Main physicochemical properties of fuels used in research.

\begin{tabular}{|c|c|c|}
\hline & ON & Emulsion \\
\hline Calorific value $(\mathrm{MJ} / \mathrm{kg})$ & 43.5 & 36.5 \\
\hline Density at $15^{\circ} \mathrm{C}\left(\mathrm{kg} / \mathrm{m}^{3}\right)$ & 0.84 & 0.86 \\
\hline Water content by volume $(\%)$ & - & 15 \\
\hline
\end{tabular}


For measuring toxic exhaust emissions of $\mathrm{CO}, \mathrm{HC}$, and $\mathrm{NO}_{x}$ we used an AVL CEB II exhaust gas analyzer. For measuring particulate matter in the exhaust gases we used a HORIBA Mexa 1230PM analyzer, which measures particulate matter in the real-time [23].

\section{Results}

Figs 5-8 show the calculated temperature of the working fluid in the cylinder. Selected operating parameters of the engine, based on the calculations from results of the test stand, are presented in the charts below (Figs 9-11.). The concentrations of $\mathrm{CO}, \mathrm{HC}, \mathrm{NO}_{x}$, and PM measured during the test are given in Figs 1213. Fig. 14 shows the result of $\mathrm{C} 1$ cycle compliant with ISO 8178 calculated for diesel fuel and emulsion.
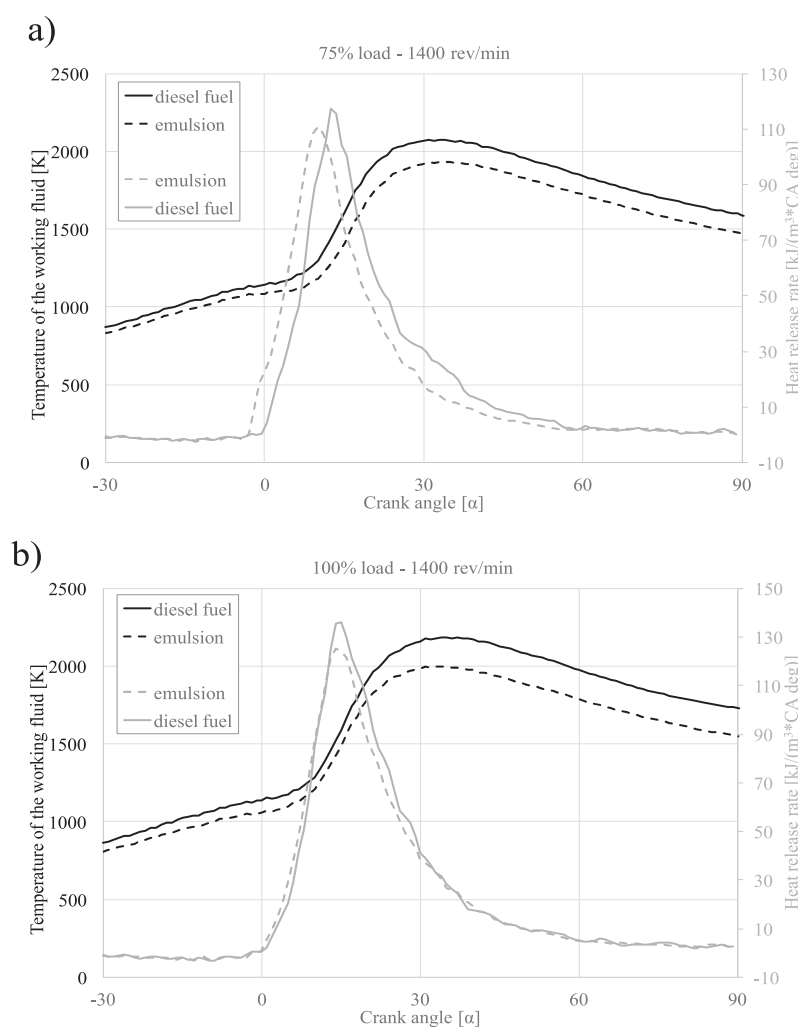

Fig 6. Temperature of working fluid in the combustion chamber and heat release rate of engine supplied with diesel fuel and emulsion under $75 \%$ a) and $100 \%$ b) load for engine speed of $1,400 \mathrm{rev} / \mathrm{min}$.

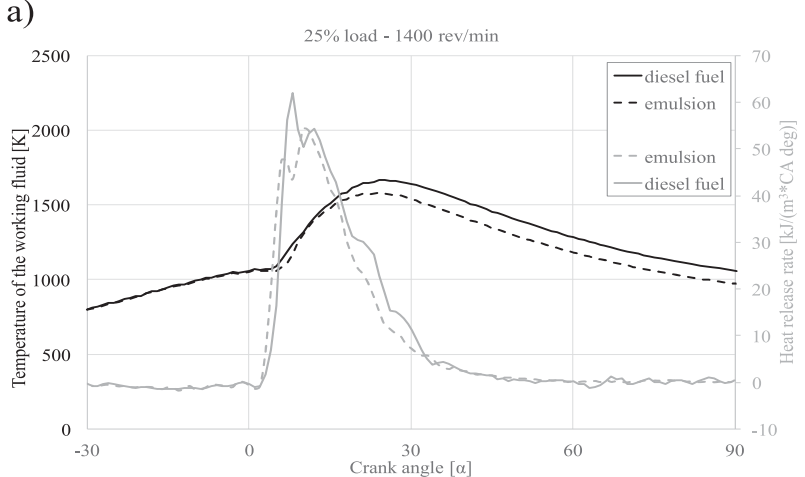

b)

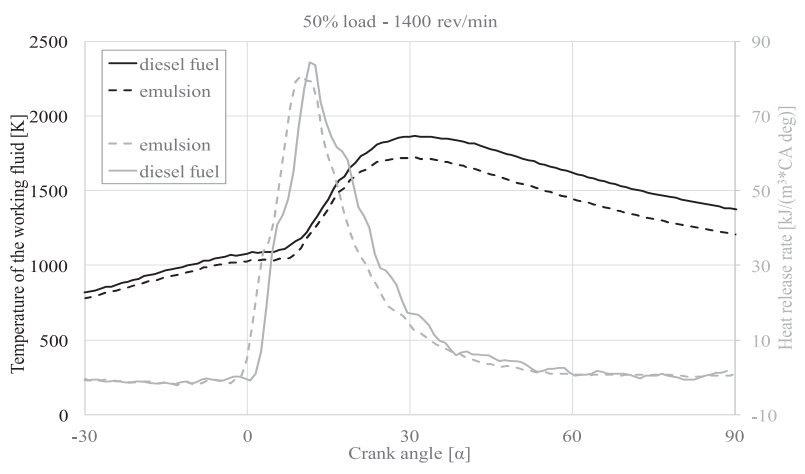

Fig. 5. Temperature of working fluid in the combustion chamber and heat release rate of engine supplied with diesel fuel and emulsion under $25 \%$ a) and $50 \%$ b) load for engine speed of $1,400 \mathrm{rev} / \mathrm{min}$. a)
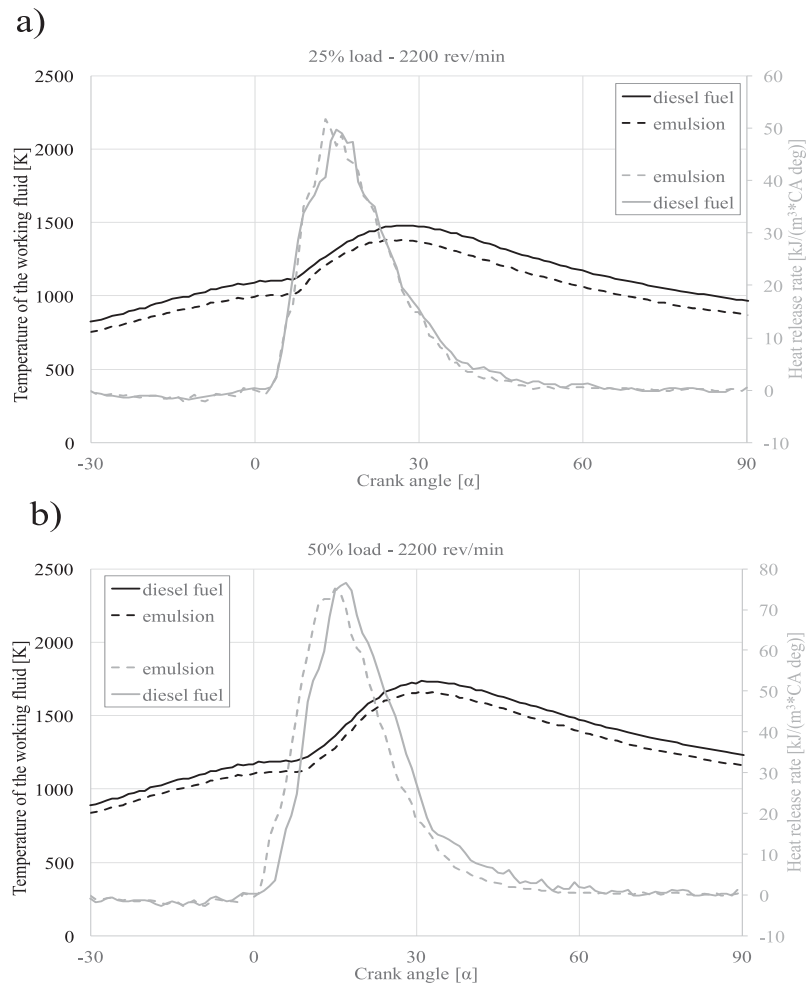

Fig. 7. Temperature of working fluid in the combustion chamber and heat release rate of engine supplied with diesel fuel and emulsion under $25 \%$ a) and $50 \%$ b) load for engine speed of $2,200 \mathrm{rev} / \mathrm{min}$. 
a)

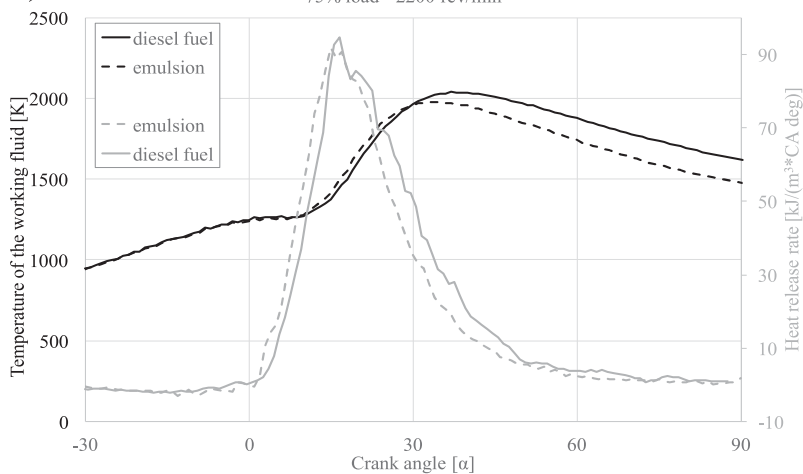

b)

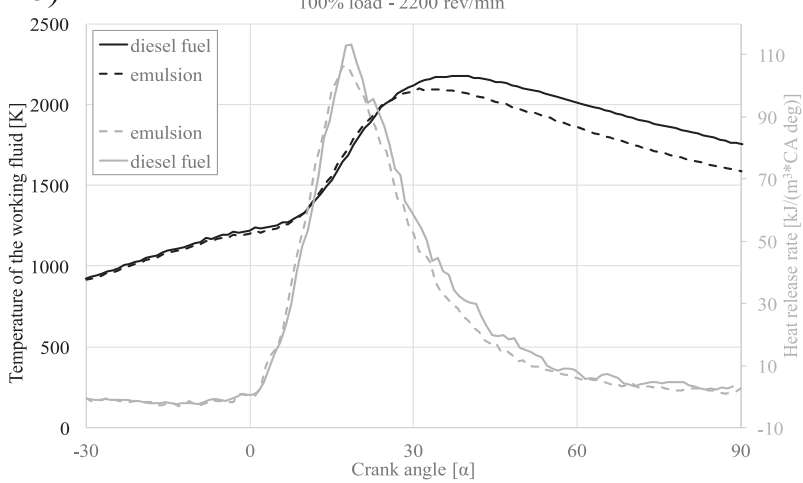

Fig. 8. Temperature of working fluid in the combustion chamber and heat release rate of engine supplied with diesel fuel and emulsion under $75 \%$ a) and $100 \%$ a) load for engine speed of $2,200 \mathrm{rev} / \mathrm{min}$.

a)

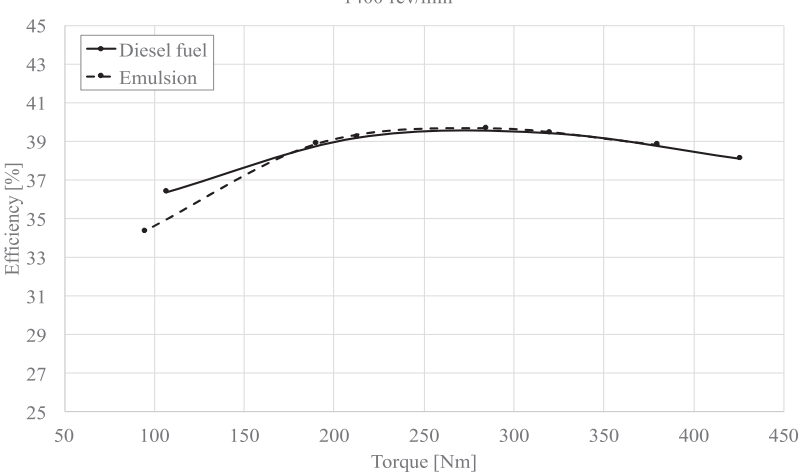

b)

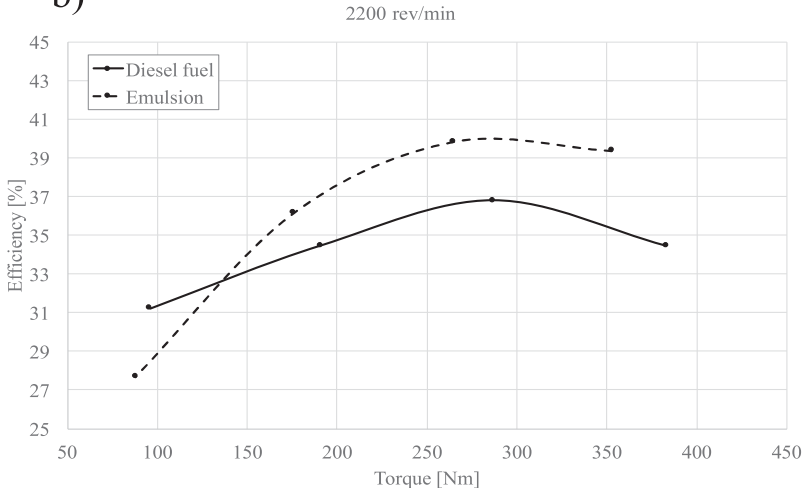

Fig. 9. Efficiency $\eta$ of engine supplied with diesel fuel and emulsion for two speeds: 1,400 a) and 2,200 rev/min b) during the research. a)
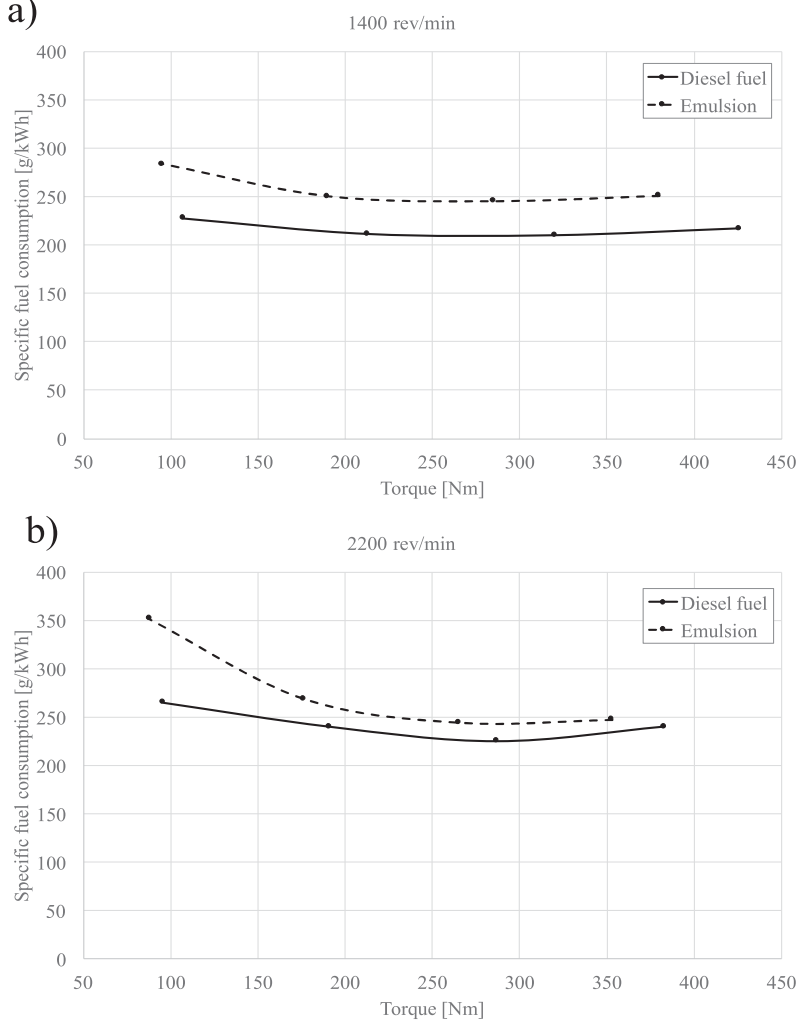

Fig. 10. Specific fuel consumption ge of engine supplied with diesel fuel and emulsion for two: speeds 1,400 a) and 2,200 rev/ min b) during the research.

a)

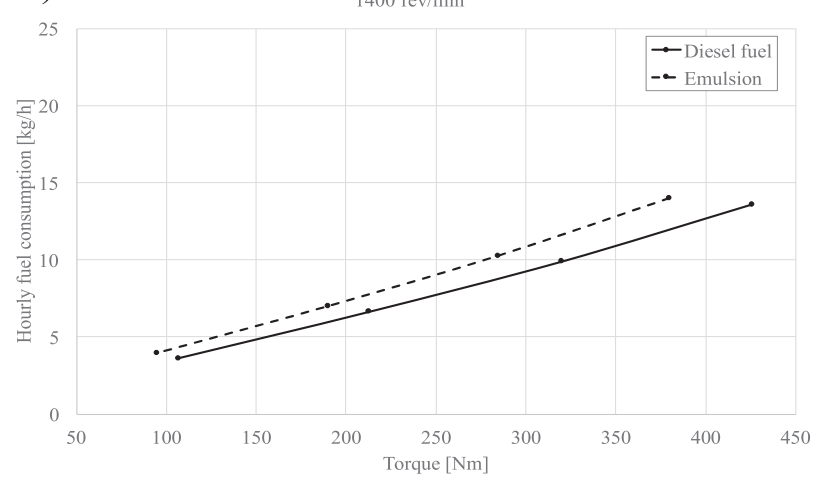

b)

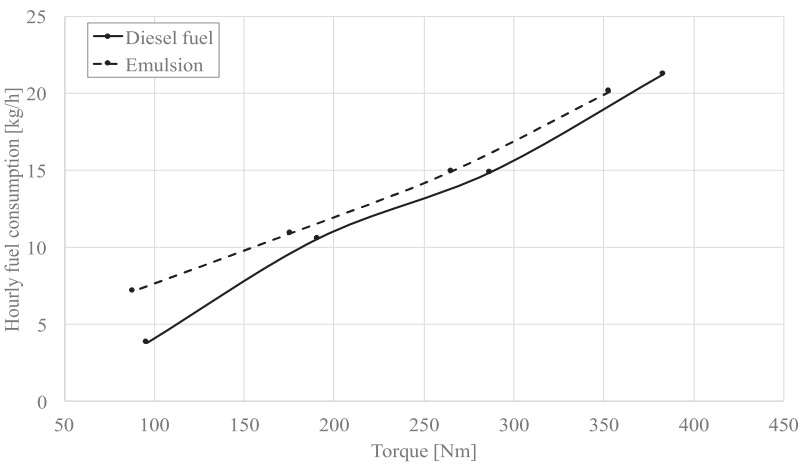

Fig. 11. Hourly fuel consumption $G e$ of engine supplied with diesel fuel and emulsion for two speeds: 1,400 a) and 2,200 rev/ min b) during the research. 
a)

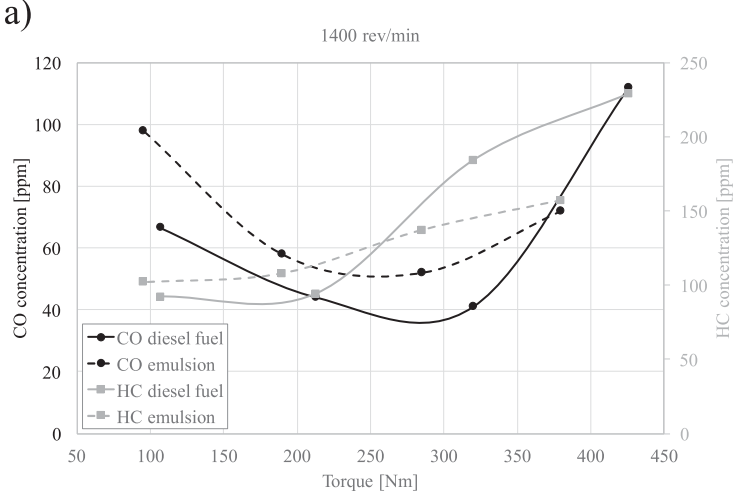

b)

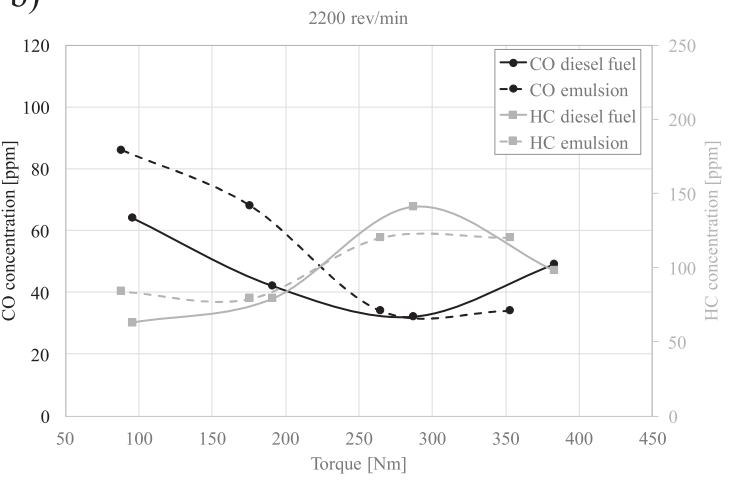

Fig. 12. $\mathrm{CO}$ and $\mathrm{HC}$ concentrations of engine supplied with diesel fuel and emulsion for two speeds: 1,400 a) and 2,200 rev/ $\min b$ ) during the research.

a)

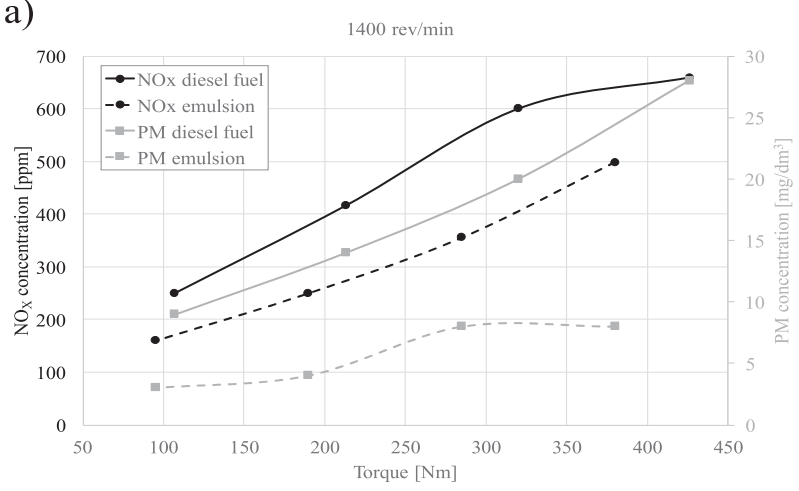

b)

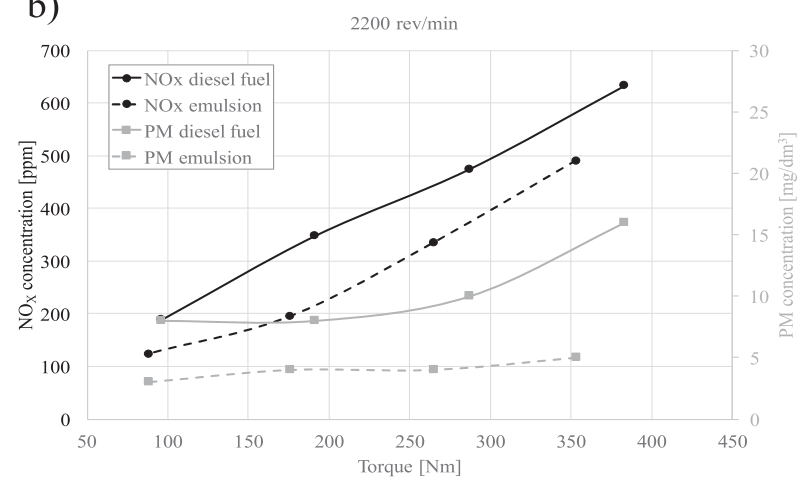

Fig. 13. $\mathrm{NO}_{\mathrm{x}}$ and $\mathrm{PM}$ concentrations of engine supplied with diesel fuel and emulsion for two speeds: 1,400 a) and 2,200 rev/ $\min b$ ) during the research.

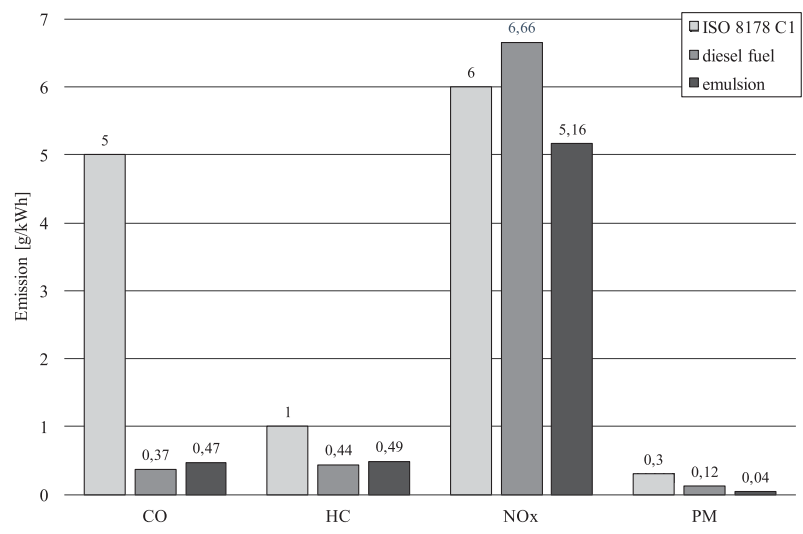

Fig. 14. Emissions of toxic exhaust gas components of engine supplied with diesel fuel and emulsion in reference to ISO 8178 , cycle $\mathrm{C} 1$.

\section{Conclusions and Discussion}

The experimental research of two fuels that we conducted - water-fuel emulsion and traditional diesel fuel - was to prove the influence of supplied fuel on operating parameters of the engine, selected combustion parameters (heat release rate, combustion temperature), and concentrations and emissions of toxic exhaust gas components. The tests for each fuel were performed at the same engine speed-load conditions and ambient conditions. Concerning the water-fuel emulsion, the important factors due to its properties were preparation and stability issues.

Obtained results proved that supplying an engine with water-fuel emulsion decreases the emissions of $\mathrm{NO}_{\mathrm{x}}$ and PM, but also has a negative impact on decreasing the operational parameters of the engine. Expected lower emissions of $\mathrm{NO}_{x}$ and $\mathrm{PM}$ were also confirmed in analyzed studies [10-11, 24-27]. Moreover, as a result of the investigation it can be stated that the stability of water-fuel emulsion 30 days after establishment is on a similar level to just after establishing. The stability of emulsion after more than a one-month period was not the case of this study. An important issue when using water-fuel emulsions is also the cost of emulsifiers that are necessary during the process of creation, and additional time, which is unavoidable as well.

Based on the obtained results, it can be stated that supplying an engine with diesel fuel and water-fuel emulsion:

- Decreases the temperature of the working fluid in the cylinder at each engine operating point considered (Figs 5-8.).

- Influences the heat release rate in the form of a visible reduction, especially under low and medium engine loads (Figs 5, 8.).

- Slightly increases CO levels, in particular at low engine loads (Fig. 12); this increase can be explained by the reduction of temperature of the combustion process due to the presence of water, and thus the 
deterioration of fuel combustion conditions as well as the increase in the content of incompletely burned coal particles.

- Does not significantly affect the emission of hydrocarbons (Fig. 12).

- Reduces $\mathrm{NO}_{x}$ emissions (Fig. 13.), which is the result of the lower temperature in the cylinder during the engine cycle because the water from the emulsion is delivered to the flame zone in the cylinder or to the area in the direct $\mathrm{NO}_{\mathrm{x}}$ formation.

- Reduces emissions of particulate PM (Fig. 13), which can by explained by the presence of water vapor in the combustion chamber working as a catalyst that helps burning carbon particles and other components difficult to oxidize.

- Increases specific fuel consumption (Fig. 10), which may be due to the lower calorific value of the waterfuel emulsion and hence the need to provide a higher dose to the cylinder.

- Causes a slight increase in engine efficiency at 2,200 $\mathrm{rev} / \mathrm{min}$ (Fig. 9b) - the maximum output of the engine. Physicochemical properties of the water-fuel emulsions have a significant impact on combustion process compared to conventional diesel fuel. This dependence also has been confirmed in research $[2-3,10,28-30]$. Decreasing the temperature in the cylinder during combustion simultaneously decreases concentrations, which is a consequence of lower nitrous oxide emissions. On the other hand, deterioration of operational parameters of the engine, e.g., specific fuel consumption, is a result of the lower calorific value of the emulsion used. Similar conclusions were found by $[3,10$, 25, 31-32].

Further research concerning elimination of negative consequences resulting in supplying the engine with water-fuel emulsions will be investigated in further scientific studies. They will involve the estimation of shelf life of the emulsion as well as complex analysis of the combustion processes, depending on the storage period. In conclusion, the obtained results prove that water-fuel emulsion can replace fuel for traditional diesel fuel even without changes to the engine fuel system.

\section{References}

1. TAYAMA K., TOSA Y., NAGAE Y., ISHIDA M. Water Mixing Combustion for Low $\mathrm{NO}_{\mathrm{X}}$ Diesel Engine, JSME, 1995.

2. MERKISZ J., PIASECZNY L. Wpływ zasilania emulsją paliwowo-wodną na toksyczność i wskaźniki pracy okrętowego, średnioobrotowego silnika spalinowego. Journal of KONES, Combustion Engines, 8 (3-4), 2001.

3. JANKOWSKI A. Microemulsion as a means of NOx reduction in exhaust emission of diesel engines. Journal of KONES, 23 (3), 225, 2016.

4. FAHD M., CHOU Y., YAP C. Experimental investigation of the performance and emission characteristics of direct injection diesel engine by water emulsion diesel under varying engine load condition. Applied Energy, 102, 1042, February 2013.
5. BASKAR P., KUMAR S.A. Experimental investigation on performance characteristics of a diesel engine using diesel-water emulsion with oxygen enriched air, Alexandria Engineering Journal, 24 October 2016.

6. KRISHNA M.B. DI diesel engine fuelled with transesterified CSO and water emulsion- an experimental study. J. Technological Advances and Scientific Res. 2 (4), 172, 2016, DOI: $10.14260 /$ jtasr $/ 2016 / 31$.

7. DUBEY M., SAXENA V. Impact of Emulsified Water/ Diesel Mixture on Engine Performance and Environment, International Journal of Engineering Trends and Technology (IJETT) - 36 (9), June 2016.

8. BACZEWSKI K., KAŁDOŃSKI T. Paliwa do silników o zapłonie samoczynnym, WKŁ 2008.

9. WIRBELEIT F., ENDERLE CH., LEHNER W., RAAB A., BINDER K. Stratified Diesel Fuel-Water-Diesel Fuel Injection Combined with EGR - The Most Efficient InCylinder $\mathrm{NO}_{\mathrm{x}}$ and PM Reduction Technology, SAE nr 972962, 1997.

10. SENTHUR N.S., RAVIKUMAR T.S. An Experimental Investigation On Performance, Combustion and Emission Parameters Biodiesel-Water Emulsion on a DI Diesel Engine. International Journal of Engineering Sciences \& Research Technology, 5 (8), August, 2016.

11. CHEN G., TAO D. An experimental study of stability of oil-water emulsion. Fuel Processing Technology, 86 (5), 499, 25 February 2005.

12. MAJEWSKI W., KHAIR K. Diesel Emissions and Their Control, SAE International, 2006.

13. LAKSHMINARAYANAN P.A., AGHAV Y. Modelling Diesel Combustion, Springer, 2010.

14. CORREA S., ARBILlA G. Aromatic hydrocarbons emissions in diesel and biodiesel exhaust. Atmospheric Environment, 40 (35), 6821, November 2006.

15. KRUCZYŃSKI S., DANILCZYK W., KAMELA W. Mikroemulsje paliwowo wodne do zasilania silników spalinowych o zapłonie samoczynnym, Silniki Spalinowe, PTNSS -2009-SC-167.

16. CHEN D.H., QI, H., MATTHEWS R.D., BIAN Y. Combustion and emission characteristics of ethanolbiodiesel-water micro-emulsions used in a direct injection compression ignition engine. Fuel, 89 (5), 958, May 2010.

17. YAHAYA KHAN M., KARIM ABDUL Z.A., HAGOS F.Y., AZIZ A.R., TAN I.M. Current Trends in Water-inDiesel Emulsion as a Fuel, The Scientific World Journal, Volume 2014 (2014), Article ID 527472.

18. PATEL N.S., MODI M., PATEL T. Investigation of Diesel Engine with Water Emulsifier - A Review, International Research Journal of Engineering and Technology, 04 (02), Feb. 2017.

19. TOROPOV S.Y., BERG V.I., PETRYAKOV V.A., MOSTOVAYA N.A. Calculation of the Thermal Parameters and Change in The Share of Emissions of Harmful Substances During Combustion of Water-Fuel Emulsion, Materials Science and Engineering 154, 2016.

20. SRINIVASA R.M., ANAD R.B. Working Characteristics of a DICI Engine by Using Water Emulsion Biodiesel Fuels, Applied Mechanics and Materials, 2014 Trans Tech Publications, Switzerland.

21. TESFA B., MISHRA R., GU F., BALL A.D. Water injection effects on the performance and emission characteristics of a CI engine operating with biodiesel. Renewable Energy, 37 (1), 333, January 2012.

22. http://www.dieselnet.com

23. http://www.horiba.com 
24. RAMLANA N.A., YAHYAA W.J., ITHNINA A.M., HASANNUDDINA A.K., NORAZNIA S.A., MAZLANA N.A., SUGENGA D.A., BAHARA N.D., KOGAB T. Performance and emissions of light-duty diesel vehicle fuelled with non-surfactant low grade diesel emulsion compared with a high grade diesel in Malaysia. Energy Conversion and Management, 130, 192, 15 December 2016.

25. BOGARRA-MACIAS M., DOUSTDAR O., FAYAD M. A., WYSZYŃSKI M. L., TSOLAKIS A., DING, PACEK A., MARTIN P., OVEREND R., O'LEARY S. Performance of a drop-in biofuel emulsion on a single-cylinder research diesel engine. Combustion Engines 55 (3), 9, 2016.

26. KAMELA W. Evaluation of the influence of powering a self-ignition engine with fuel-water emulsion on the parameters of its operation and the concentration of toxic substances in exhaust gases, Proceedings of the Institute of Vehicles 4 (108)/2016.

27. SCARPETE D. Diesel-water emulsion, an alternative fuel to reduce diesel engine emissions. A review, Machines, Technologies, Materials. Issn 1313-0226. Issue 7/2013.
28. VELLAIYAN S., AMIRTHAGADESWARAN K.S Multi-response optimization of diesel engine operating parameters running with water-in-diesel emulsion fuel. Thermal Science 2016 OnLine-First Issue, Pages: 220-220.

29. SENTHIL R., ARUNAN K., SILAMBARASAN R. Experimental Investigation of a Diesel Engine fueled with emulsified biodiesel. International Journal of ChemTech Research, 8 (1), 190, 2015.

30. SANGEETA D. Performance Evaluation of CI Engine Fuelled with Water Emulsified Diesel Oil. International Journal of Research in Engineering and Technology, 05 (11), November 2016.

31. OGUNKOYA D., LI S., ROJAS O.J., FANG T. Performance, combustion, and emissions in a diesel engine operated with fuel-in-water emulsions based on lignin, Applied Energy, 154, 851, 15 September 2015.

32. RAHEMAN H., KUMARI S. Performance and Emissions of Emulsified Biodesel Operated Diesel Engine, International Conference on Biological, Civil and Environmental Engineering, March 17-18, 2014 Dubai. 